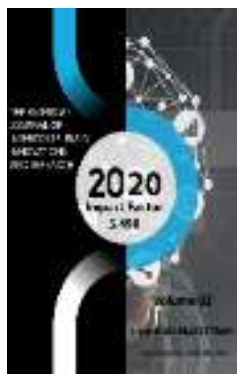

Journal Website: http://usajournalshub.c om/index,php/tajiir

Copyright: Original content from this work may be used under the terms of the creative commons attributes 4.0 licence.

\section{Features Of Influence Of Industrial Enterprises Almalyk City On The Geological Environment}

\author{
Yusuf Pulatovich Isomatov \\ Senior Lecturer, Almalyk Branch Of Tashkent State, Technical University Named After Islam \\ Karimov, Uzbekistan
}

Mukhammadzhakhongir Kidirbaevich Akhmedov

Senior Teacher, Almalyk Branch Of Tashkent State, Technical University Named After Islam Karimov, Uzbekistan

Server Ibadlaevich Ibadlaev

Senior Teacher, Almalyk Branch Of Tashkent State, Technical University Named After Islam Karimov, Uzbekistan

\title{
ABSTRACT
}

The article considers that the course of more than 5 decades as a result of the infiltration of contaminated waters of open pits, dumps, slag accumulators of the copper smelting plant (CSP), the production association (PA) "Ammophos", tailing dumps of copper concentrating factories (CCF - 1 and CCF -2), as well as due to the leakage of reagents from the sulfuric acid shop through rocks that are not consistent in area and insignificant thickness of loess-like loams, and the penetration of polluting components into the aquifer occurs. Due to the action of the infiltration flow, a change in the chemical composition of soils occurs on solid soil particles, a number of chemical compounds are sorbed.

The article provides recommendations for reducing the pollution of the geological environment.

\section{KEYWORDS}

Technological processes, geosystem, geoecology, natural landscape, tailing dump, self-cleaning process, water-bearing rocks, adsorption, infiltration, chronic pollution.

\section{INTRODUCTION}

The development of industry within the Tashkent region caused an anthropogenic metamorphosis of the qualitative composition of both surface and groundwater interconnected with them. Only within the valleys of the Akhangaran river, there are, respectively, about 20 or more industrial, municipal and other enterprises, which are 
concentrated, mainly in the cities of Almalyk, Akhangaran and also the adjacent territories.

\section{MAIN PART}

In the Almalyk mining and industrial region, the development of the mining and processing industry, urban construction, urban economy, along with great importance in the economy of the republic, has a significant negative impact on the environment. At the same time, its intensive change and deterioration of the state of geoecological conditions occur, the natural landscape changes, peculiar forms of relief are formed, represented by quarries, dumps, tailing dumps of JSC Almalyk Mining and Metallurgical Combine (AMMC), Ammophos Production Association and other industrial enterprises. Without touching on the issues of technology for the extraction, transportation and processing of raw materials, we note that now an important task is the further development and implementation of technological processes for the processing of massive industrial waste products in order to reduce environmental pollution. [1;2]

\section{RESULTS AND DISCUSSIONS}

When analyzing the impact of industrial waste on the natural environment, special attention is paid to the following factors: area of distribution, impact on the relief, soil, surface and ground waters.

At present, the area of land on which the waste of copper concentrating factories (CCF-1 and (CF-2) is located, and the waste of the copper smelting plant (CSP) and production association Ammophos is more than $10 \mathrm{~km} 2$. The base of the tailings storage ponds (old) of the CCF, slag storage ponds of the CSP and waste of the Ammophos production association is the II accumulative terrace of the Syrdarya complex of Quaternary deposits. It is represented from above by a thin (0,5-1,5 m) sandy-loamy soil-vegetation cover, below by gravel-pebble deposits with a thickness of more than $15-20 \mathrm{~m}$ and with a groundwater depth of 8-10 $\mathrm{m}$ and more. [3]

In the areas below the industrial sites of the JSC Amalyk Mining and Metallurgical Combine and the Almalyk Chemical Plant, groundwater salinity is $0,8-1,0 \mathrm{~g} / \mathrm{I}$ and depending on the mode of operation of the pollution source, the season of the year, etc.

Localized contaminated areas are noted below the tailing dump at the copper concentrating factories (CCF). Here, in groundwater, the manganese content occasionally exceeds the MPC. Among other pollutants, molybdenum, copper, lead, zinc in concentrations up to 0,5 MPC were recorded.

The increased areal pollution of groundwater in the middle and lower parts of the Akhangaran river valley is associated with nitrogenous compounds, which tends to change the quality of groundwater towards deterioration.

The combined tailing dump (new) CCF-1 and CCF-2 are located within the III terrace of the Holodostep erosion-accumulative cycle, represented by a 2 and $3 \mathrm{~m}$ cover of loam, and below by coarse (gravel) sediments.

Uplands formed from waste products of the Ammophos Production Association, CSP, tailing dumps CCF-1 and CCF-2 (Fig. 1), exceeding the absolute elevations of the territory by $15-35 \mathrm{~m}$. The natural 
microreliefdisappeared, a new anthropogenic relief was formed.

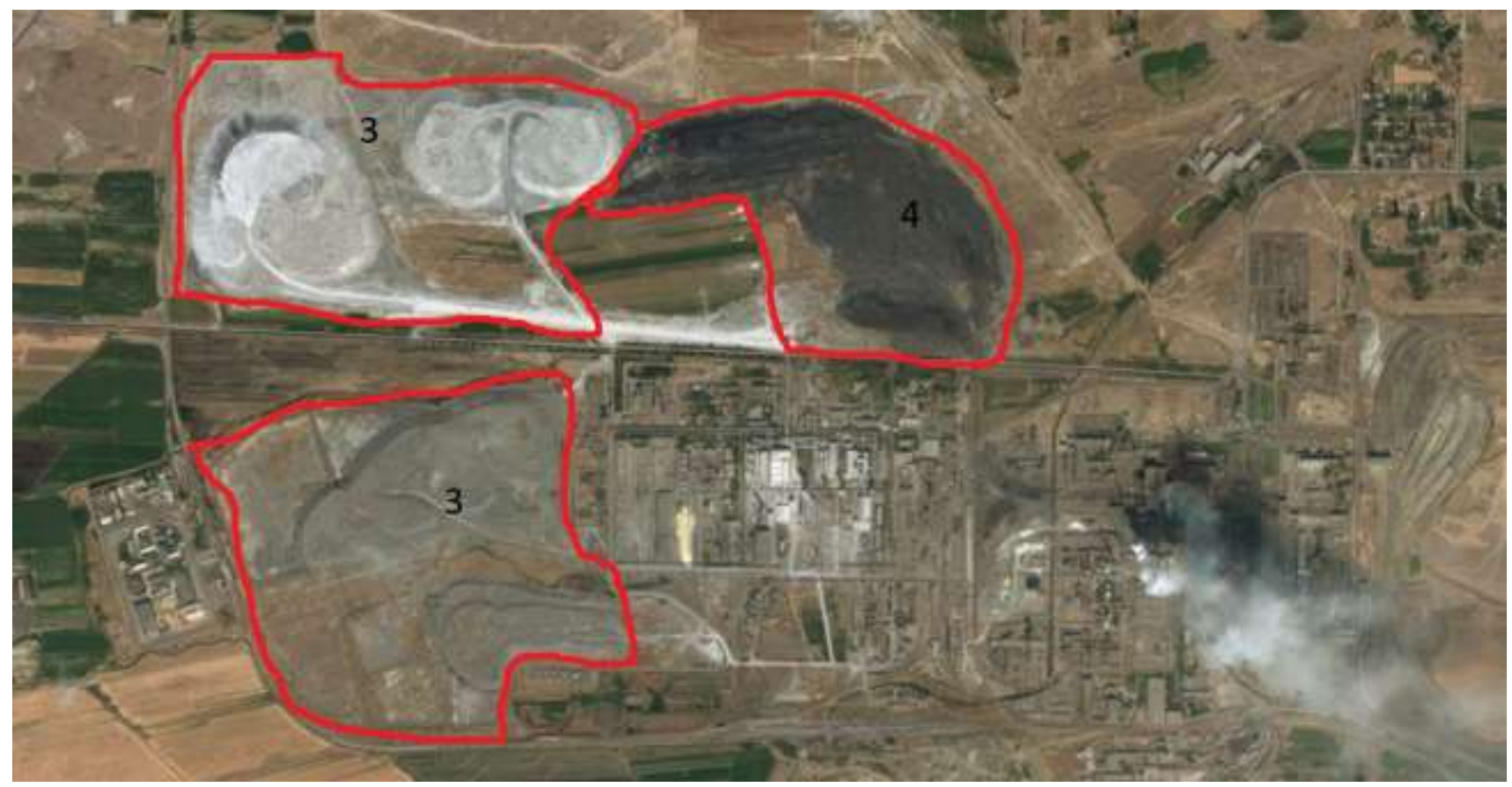

Fig. 1. Waste locations of PA "Ammophos" (3) and slag from CSP (4)

The thickness of the soil and vegetation layer on the territory is $0,2-0,5 \mathrm{~m}$. Due to the action of the totality of soil organisms, chemical and biochemical reactions, plants ha-ve the opportunity to feed on organic substances, the required amount of which in the last century Liebig called the law of minimum [1]. Now this regularity is violated by the presence in soils of increased concentrations of nitrogen, $\mathrm{Na}$, $\mathrm{NO}_{2} \mathrm{NO}_{3}$ and $\mathrm{SO}_{2} 24, \mathrm{SO}-3 \mathrm{NH}_{4}$, $\mathrm{HF}$.

The change in the properties and composition of soils that make up the territory occurs in three directions. This is, firstly, the compaction of rocks under the body of storage ponds, which leads to a change in the physical and mechanical properties, an increase in moisture and a decrease in the porosity of rocks, a change in density, strength parameters. Thus, the density values of sandy loamy-loamy soils from the weight of technogenic massifs change from 1,45 to $2,20 \mathrm{~g} / \mathrm{cm} 3$, porosity from $55 \%$ to $40 \%$, the value of the angle of internal friction from $28^{\circ}$ to $24^{\circ}$, shear resistance depending on moisture and soil density from 0,062 to $1,175 \mathrm{MPa}$.

In the zone of influence of the tailing dumps CPF-1 and CCF-2 (Fig. 2), due to the action of the infiltration flow, changes in the physical composition of soils occur, readily soluble compounds are washed out (bicarbonates HCO3-1. Sulfates - SO4-11. Chlorides-(-1), a number of chemical compounds are sorbed on solid soil particles: copper, cadmium, bismuth, lead, molybdenum, manganese, zinc, rhenium, arsenic and others [3;4]. 


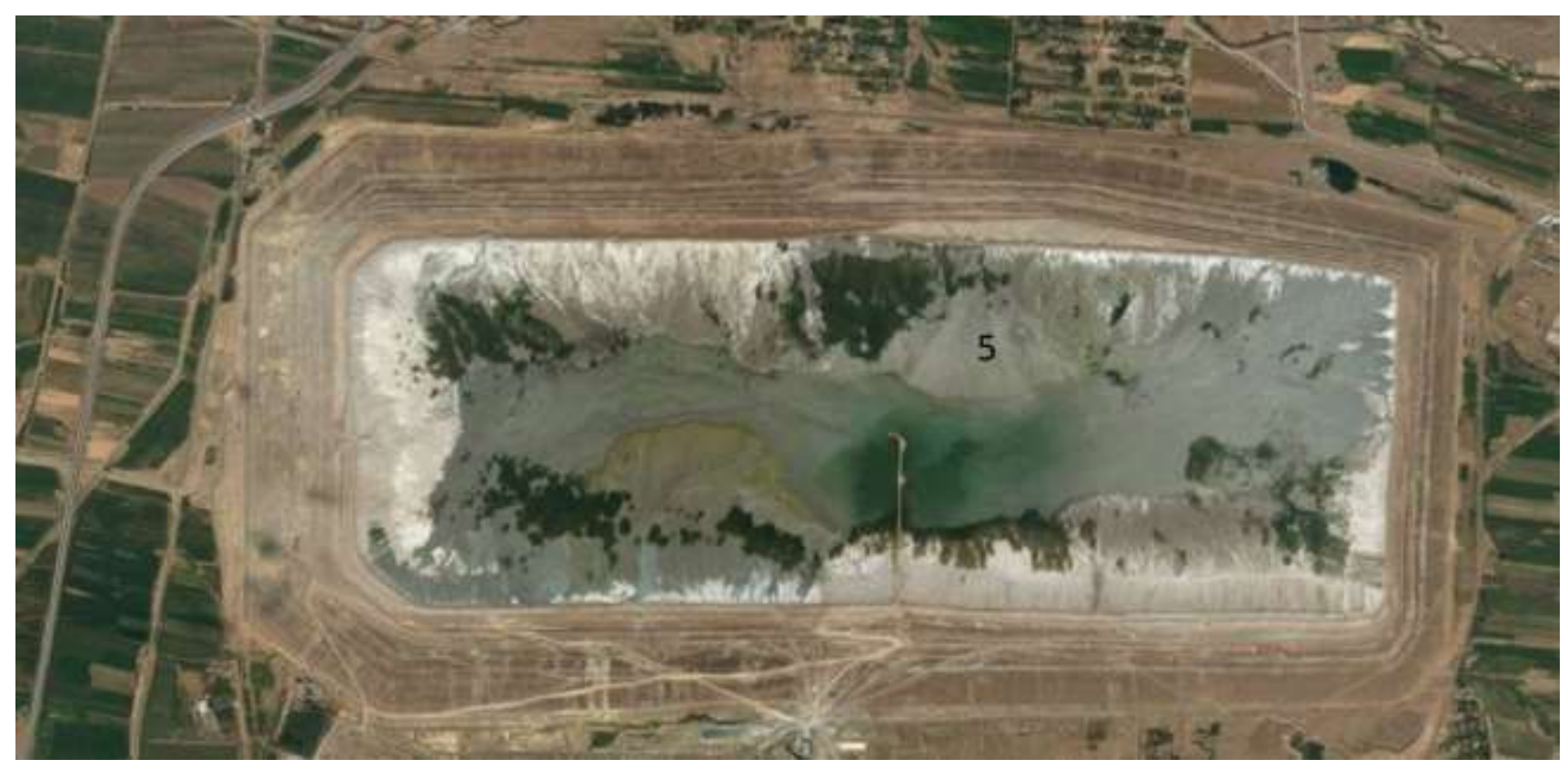

Fig. 2. Tailings dumps CCF-1 and CPF-2

There is information about intense contamination of the soils of the area around the tailing dump to a depth of $10 \mathrm{~m}$ with heavy metals and other toxic elements (lead, zinc, arsenic, copper, antimony, tungsten, vanadium, etc.) reaching 50-80 MPC. Copper pollution of soils sac companied by carbonate pollution [5].
The main sources of pollution of surface and underground water bodies are the mines of Kurgashinkan, Kauldy, Sary-Cheku, Kalmakir, waste (abandoned quarry filled with contaminated water) (Fig.3), tailing dumps CPF-1 and CPF-2, dumps of PA Ammofos, CSP, sulfuric acid workshop and other facilities of the enterprise (Fig. 1). 


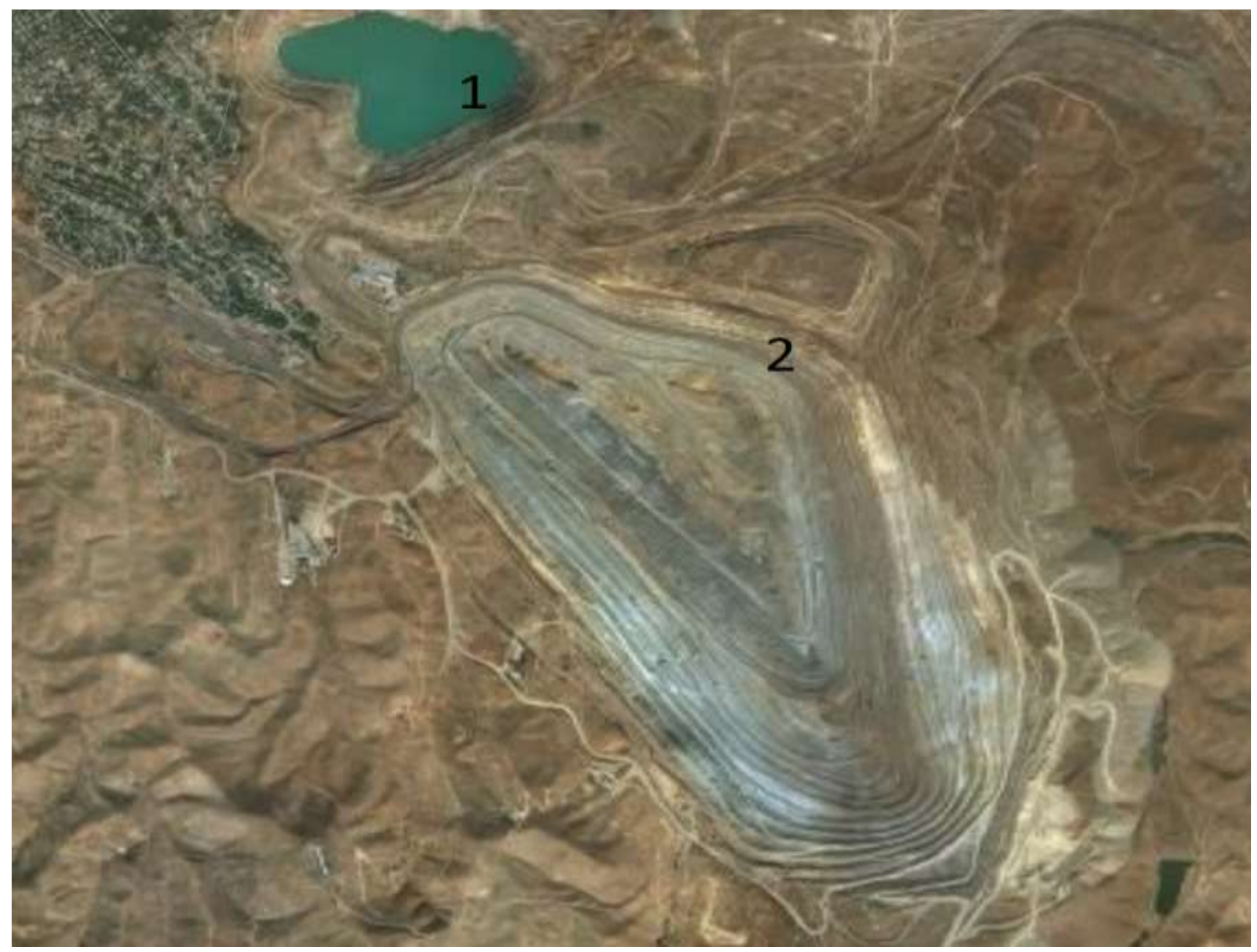

Fig. 3.Kurgashinkan (1) and Kalmakyr (2) deposits.

The ores of the Almalyk ore region contain many minerals represented by chemical compounds: $3 \mathrm{MgO} 4 \mathrm{SiO}_{2} \mathrm{H}_{2} \mathrm{O}, \mathrm{Al}_{2} \mathrm{O}_{3}, 4 \mathrm{SiO}_{2}$ $\mathrm{H}_{2} \mathrm{O}, \mathrm{CuFeS}_{2}, \mathrm{Cu}_{2} \mathrm{O}, \mathrm{Cu}_{5} \mathrm{FeSO}_{4}$; $\mathrm{CuS} ; \mathrm{FeS}_{2} ; \mathrm{Fe}_{2} \mathrm{~S}_{3}$; $\mathrm{Sb}_{2} \mathrm{~S}_{3}$; FeAsS; $\mathrm{As}_{2} \mathrm{~S}_{3}$; HgS; CoAsS; $\mathrm{As}_{2} \mathrm{O}_{3} ; \mathrm{MoS}_{2}$; $\mathrm{Ag}_{2} \mathrm{~S} ; \mathrm{S} ; \mathrm{Fe}_{3} \mathrm{O}_{4} ; \mathrm{Fe}_{2} \mathrm{O}_{3} ; \mathrm{CuSiO}_{3} ; \mathrm{HH}_{2} \mathrm{O} ; \mathrm{PbSO}_{4}$; $\mathrm{PbS} ; \mathrm{ZnS} ; \mathrm{ZnSO}_{3} ; \mathrm{BaSO}_{4}$ and others. Dumps of PA "Ammophos" contain: $\mathrm{CaSO}_{4} \quad 2 \mathrm{H}_{2} \mathrm{O}$ или $\left(\mathrm{CaO} ; \mathrm{SO}_{3} ; \mathrm{H}_{2} \mathrm{O}\right) ; \mathrm{MgCO}_{3} ; \mathrm{SiO}_{2} ; \mathrm{Fe}_{2} \mathrm{O}_{3} ; \mathrm{P}_{2} \mathrm{O}_{5}$; $\mathrm{HF}$;and etc.

CSP dumps contain: $\mathrm{FeO} ; \mathrm{Fe}_{2} \mathrm{O}_{3} ; \mathrm{Fe}_{3} \mathrm{O}_{4} ; \mathrm{ZnO}$; $\mathrm{CuO} ; \mathrm{CaO} ; \quad \mathrm{FeOSiO}_{2} ; \quad \mathrm{Al}_{2} \mathrm{O}_{3} ; \quad \mathrm{Al}_{2} \mathrm{O}_{3} ; \mathrm{As}_{2} \mathrm{~S}_{3}$; $\mathrm{As}_{2} \mathrm{O}_{3} ; \mathrm{SiO}_{2} ; \mathrm{FeAsS}$.
With the assistance of groups of bacteria, converters of mineral substances, when deposited in ore dumps containing the above chemical compounds, chemical weathering occurs. It is known that these basic bacteria are capable of leaching copper and other nonferrous metals, sulfide compounds. Ferrobacillus Ferrooxidons bacteria can oxidize $0,02 \% \mathrm{Fe}$ (3) in three days [6;7]. The optimum temperature for the activity of bacteria is 28 $30^{\circ} \mathrm{C}$, which is typical for this area. Iron oxidation by bacteria occurs according to the reaction: 


$$
\begin{gathered}
2 \mathrm{FeSO}_{4}+\mathrm{O}, 5 \mathrm{O}_{2}+\mathrm{H}_{2} \mathrm{SO}_{4} \rightarrow \mathrm{Fe}_{2}\left(\mathrm{SO}_{4}\right)_{3}+\mathrm{H}_{2} \mathrm{O} \\
\mathrm{FeS}_{2}+3,5 \mathrm{O}_{2}+\mathrm{H}_{2} \mathrm{O} \rightarrow \mathrm{FeSO}_{4}+\mathrm{H}_{2} \mathrm{SO}_{4} \\
2 \mathrm{FeS}_{2}+7,5 \mathrm{O}_{2}+\mathrm{H}_{2} \mathrm{O} \rightarrow \mathrm{Fe}_{2}\left(\mathrm{SO}_{4}\right)_{3}+\mathrm{H}_{2} \mathrm{SO}_{4} \\
\mathrm{~S}+\mathrm{H}_{2} \mathrm{O}+1,5 \mathrm{O}_{2}=\mathrm{H}_{2} \mathrm{SO}_{4}
\end{gathered}
$$

Copper minerals are chemically and bacterially oxidized:

$$
\begin{gathered}
2 \mathrm{CuFeS}_{2}+8,5 \mathrm{O}_{2}+\mathrm{H}_{2} \mathrm{SO}_{4} \rightarrow 2 \mathrm{CuSO}_{4}+\mathrm{Fe}_{2} \\
\left(\mathrm{SO}_{4}\right)_{3}+\mathrm{H}_{2} \mathrm{O} \\
\mathrm{CuFeS}_{2}+2 \mathrm{Fe}_{2}\left(\mathrm{SO}_{4}\right)_{3}=\mathrm{CuSO}_{4}+5 \mathrm{FeSO}_{4}+2 \mathrm{SO} \\
\mathrm{Fe}_{2}\left(\mathrm{SO}_{4}\right)_{3}+6 \mathrm{H}_{2} \mathrm{O} \rightarrow 2 \mathrm{Fe}(\mathrm{OH})_{3}+3 \mathrm{H}_{2} \mathrm{SO}_{4} \\
4 \mathrm{Cu}_{2} \mathrm{~S}+9 \mathrm{O}_{2}=4 \mathrm{CuSO}_{4}+2 \mathrm{Cu}_{2} \mathrm{O}
\end{gathered}
$$

In the wastes of the tailing dump of the MOP, the predominant ions are $\mathrm{Cu}^{2+}, \mathrm{Fe}^{3+}$ and they can be oxidized by the residues of flotation reagents added at the factories.

\section{$\mathrm{CH}_{3} \mathrm{CuH}_{4} \mathrm{O}>{ }_{\mathrm{P}} /{ }^{\mathrm{S}}$
$\mathrm{CH}_{3} \mathrm{CuH}_{4} \mathrm{O}^{-}{ }_{\mathrm{SH}(\mathrm{K}, \mathrm{Na})}$}

Interacting with $\mathrm{Cu}^{2+}$ and $\mathrm{Fe}^{3+}$ ions

$$
\begin{gathered}
4(\mathrm{RO})_{2} \mathrm{P}_{5} \mathrm{~S}+2 \mathrm{Cu}^{2+} \rightarrow\left((\mathrm{RO})_{2} \mathrm{P}_{5} \mathrm{~S}\right)_{2} \mathrm{Cu}_{2}+ \\
\left((\mathrm{RO})_{2} \mathrm{P}_{5} \mathrm{~S}\right)_{2} \\
6(\mathrm{RO})_{2} \mathrm{P}_{5} \mathrm{~S}+2 \mathrm{Fe}^{3} \rightarrow\left((\mathrm{RO})_{2} \mathrm{P}_{5} \mathrm{~S}\right)_{2}+ \\
2 \mathrm{Fe}\left((\mathrm{RO})_{2} \mathrm{P}_{5} \mathrm{~S}\right)_{2}
\end{gathered}
$$

Ditophosphates are often present in the waters of tailing dumps, where intense water filtration occurs.<smiles>O=[R6]([O+])[PH](O)=S</smiles><smiles>O=[PH](S)P=S</smiles>

Reactions of this type can take place in the tailings of the concentrating factories. The process of pollution as a result of infiltration of water from open pits, dumps, slag ponds, sedimentation tanks (tailing ponds) CCF-1 and CPF-2 (Fig. 4), as well as leakage of reagents from the sulfuric acid shop through the rock aeration zones occurs for 5 decades. So, the filtration zone of the Akhangaran river valley is represented mainly by rocks with high water filtration properties (up to $10 \mathrm{~m}^{3} /$ day). The rate of spread of pollution depends on many factors: on the natural protection (covering of the aquifer with poorly permeable sediments); due to the lack of a high-quality insulated bedding at the base of the waste storage; from a sharp rise in the level of groundwater: from abundant atmospheric precipitation; due to the emergence of the water-bearing rocks of the first aquifer from the surface. [5]. 


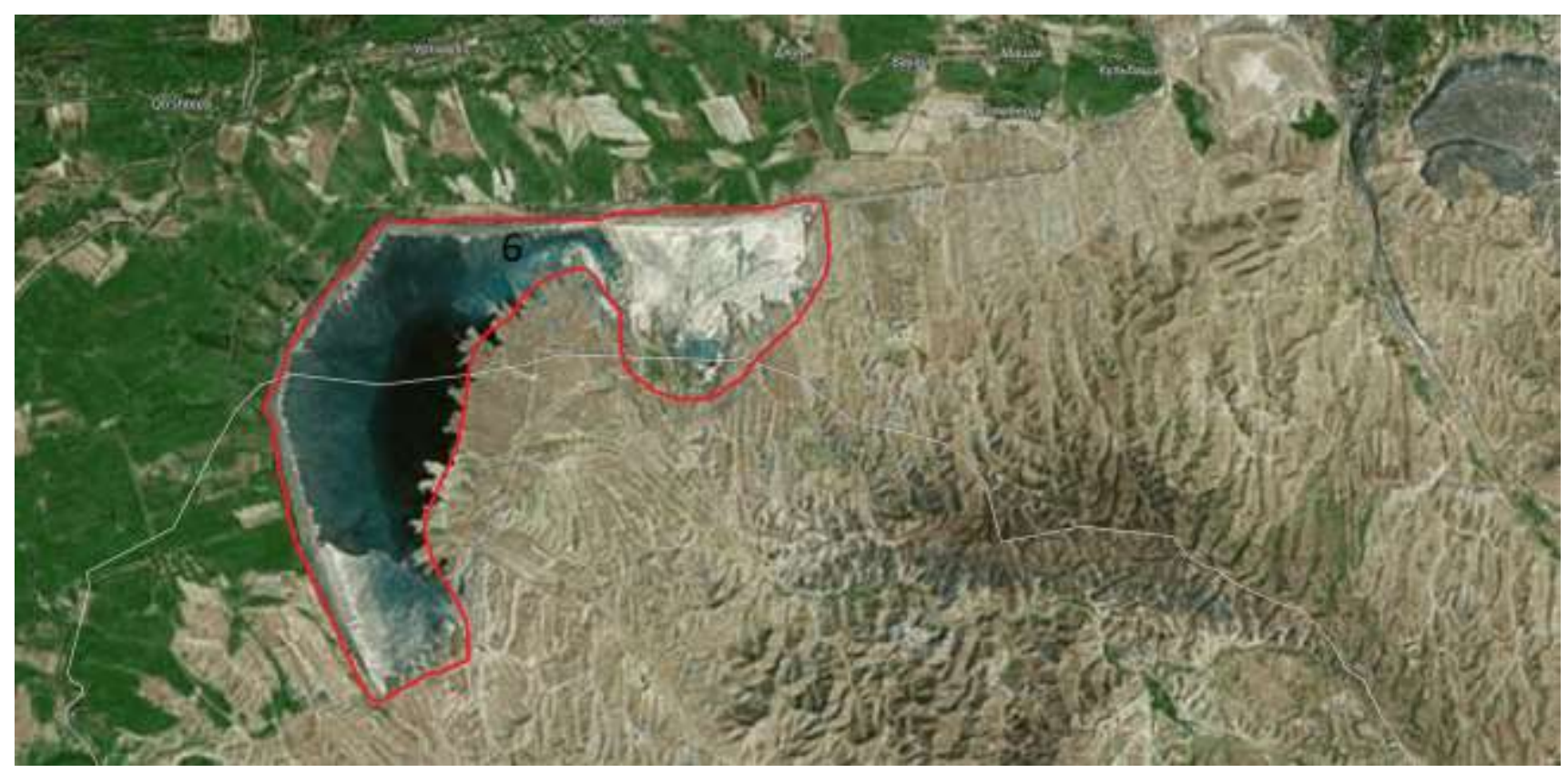

Figure: Sediment tank CCF-1 and CPF-2

The groundwater of Quaternary sediments within the region, due to the insignificant thickness of the weakly water-permeable loess-like loams, is poorly protected from the harmful effects of technogenic loads and there is a possibility of rapid penetration of polluting components into the aquifer.

In the Akhangaran valley, water-bearing rocks come to the surface and do not have a regional aquiclude. They are the main source of water supply for large settlements of the Pskent region, located hypsometrically below the Almalyk industrial region.

As it is known, submitted by R. Carbienar, the chemical pollution of groundwater at the first stage, which is temporary, then becomes chronic. In case of chronic pollution, a group of pollutants has an inhibitory effect on the selfcleaning process [7].
Mechanical contamination of surface waters is an occasional one-time discharge of waste (sludge, slag, etc.) by Ammophos Production Association, CCF-1, CPF-2, CSP, sulfuric acid workshop and other enterprises into canals and ditches as a result of pipeline accidents, tailing dumps, which are no exception in this respect.

This information shows the general nature of the pollution. However, this is not enough and it is necessary to determine the necessary indicators that follow in the whole region and depend on the branch industry and the type of industrial enterprise.

The main tasks of further research can be considered the study of quantitative factors characterizing the variability of the natural geological environment under the influence of the industry of the region. 


\section{CONCLUSIONS}

Thus, the fastest solution of urgent problems of minimizationthe harmful influence of industry on the natural environment, processing of existing man-made massifs (waste) and the introduction of waste-free production technology will improve the state of geoecological conditions and prevent environmental pollution.

Water protection measures in the identified areas with different ecological conditions are as follows:

1. For areas with favorable ecological conditions (right-bank parts of the Akhangaran river valleys), preventive water protection measures are recommended. This is to avoid the extent to which the dilution capacity of the soil flow is fully utilized. There should not be placed facilities based on technology that use accumulators of liquid waste, from which highly concentrated effluents are filtered (chemical, metallurgical, mining, oil-extracting industries, and other plants).

2. For areas with a conditionally favorable ecological state, where a negative trend of deterioration in quality is currently outlined, it is required to prevent the construction of new large industrial facilities. In existing industrial enterprises, a clear organization of water consumption accounting and strict regulation of consumption, the fight against losses and leaks are necessary.
3. For areas that are already polluted and have substandard waters in an unfavorable ecological state, it is recommended to improve the hydrochemical situation at industrial sites, increase the degree of wastewater treatment at treatment facilities, improve the technological process, and reduce the technogenic load.

\section{REFERENCES}

1. National report on the state of the environment and the use of natural resources in the Republic of Uzbekistan State Committee of the Republic of Uzbekistan for Nature Protection (2001) .Tashkent. Publishing house Ihikor EHK, 2002 $21 \mathrm{p}$.

2. IsomatovYu.P. Features of the technogenic impact of the industry of Almalyk on the natural environment. Abstracts of the city scientific and technical conference "Science of Almalyk and regional development problems".Almalyk. 2002 p. 43-44.

3. IsomatovYu.P. About the interaction of technological processes of the industry of the city of Almalyk and the geological environment.Optimization of complex technological processes in the mining and metallurgical industry.Collection of scientific papers Tashkent 1991.Publishing house.Tash.PI. 1991.from 52-55.

4. Isomatov Yu.P. Features of the technogenic impact of the industry of the AngrenAkhangaran region on the environment. Abstracts of the international scientific and technical conference "Problems and prospects for the development of science and practice in Uzbekistan."Tashkent. 2004, p. 29. 
5. Khudoyberganov A.M., NurmukhamedovK.Sh., Tuichieva M.A. et al. Geoecology and seismic ecology of cities in Uzbekistan. Toshkent "Iqtisodiot" 2014. 101 p.

6. Nikitin DP, NovikovYu.V. Environment and people. M. Nedra. 1980.11s

7. Ages P. Key to ecology. Leningrad, Gidrometeoizdat. 1982.9 p.

8. IsomatovYu.P. et al. About changes of mining-geological conditions of Kalmakyr deposits shortening. IJARSET (International Journal of AddvancedRessearch in Science, Engineering and Technology) No. 9 September 2019 yil from 10975-10979.

9. IsomatovYu.P. on the formation of the technogenic regime of groundwater during the development of the Kalmakir deposit. Mountain Bulletin of Uzbekistan. No. 4 Navoiy, p. 48.

10. Tukhtaev T. Khamidov" Fundamentals of ecology and nature protection” Tashkent. "O`qituvchi" 1994.p. 160. 